\title{
GEOMETRY OF HOLOCENE TIDAL NOTCHES - SEA LEVEL MARKERS AT PERACHORA PENINSULA, GULF OF CORINTH, GREECE
}

\author{
Schneiderwind S. ${ }^{1}$, Kázmér M. ${ }^{2}$, Boulton S. ${ }^{3}$, Papanikolaou I. ${ }^{4}$ and Reicherter K. ${ }^{1}$ \\ ${ }^{I}$ RWTH Aachen University, Institute of Neotectonics and Natural Hazards, Lochnerstraße 4-20, \\ 52056 Aachen, Germany.s.schneiderwind@nug.rwth-aachen.de \\ ${ }^{2}$ Department of Palaeontology, Eötvös University, H-1117 Budapest, Pázmány Péter sétány 1/c, \\ Hungary \\ ${ }^{3}$ Centre for Research in Earth Sciences, School of Geography, Earth and Environmental Sciences, \\ Plymouth University, Plymouth, Devon PLA 8AA, UK \\ ${ }^{4}$ Laboratory Mineralogy - Geology, Agricultural University of Athens, Iera Odos 75, Athina 118 \\ 55, Greece
}

\begin{abstract}
Tidal notches are a generally accepted sea level indicator that, when different from mean sea level, witness tectonic activity at or near coastlines. However, how to infer related information is controversial since tectonic uplift from a single seismic event is not likely to exceed several decimetres. High resolution laser scanning offers the availability of close-up views on exposures and to detect evidence for multiple sea level indicators in between major emergence. Statistically representative profiles along exposure were analysed in order to prove for already described tidal notches and to highlight similar shapes in consistent geometries along coastal cliffs of Perachora Peninsula.

Keywords: notch formation, $t$-LiDAR, tectonic uplift, palaeoshoreline.

\section{Пєрí $\eta \psi \eta$}

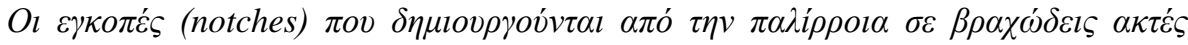

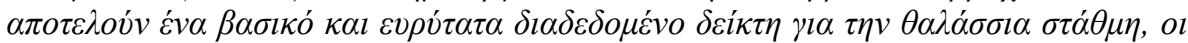

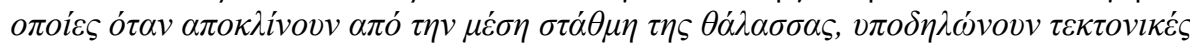

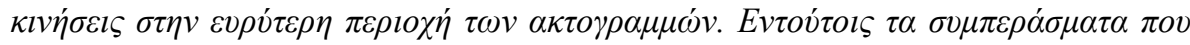

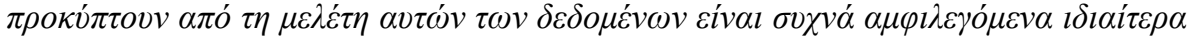

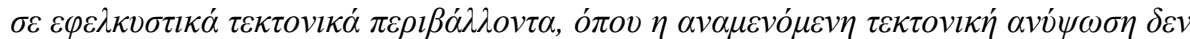

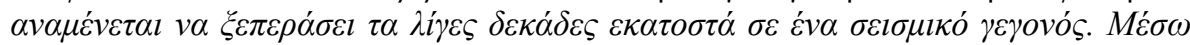

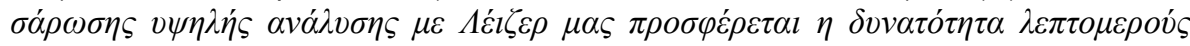

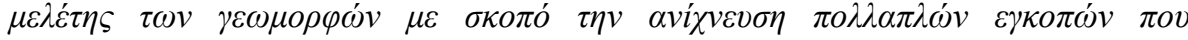

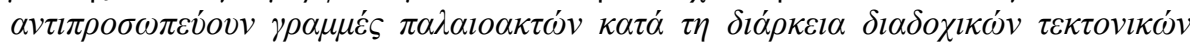

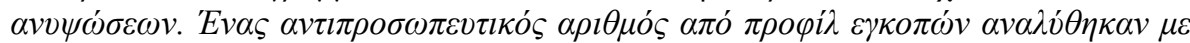

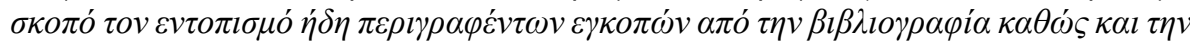

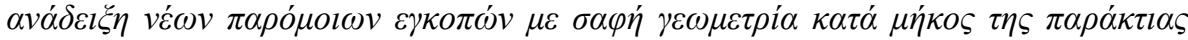

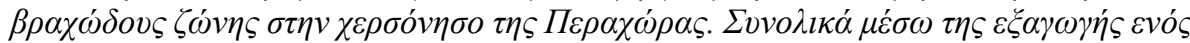

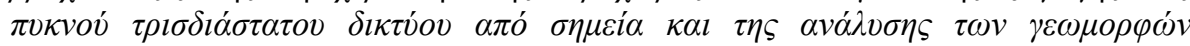




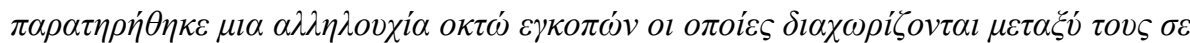
$\alpha \pi о \sigma \tau \dot{\sigma} \sigma \varepsilon l \varsigma \pi \varepsilon \rho i \operatorname{\pi ov} 0.3 \pm 0.2 \mathrm{~m}$.

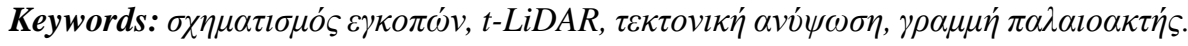

\section{Introduction}

Indentations along steep rocky calcareous coastlines have been investigated for many years, in order to derive information about Holocene relative land movements and coastal tectonic activity. Constant conditions of physical, chemical and biological erosion result in the development of distinct ecological and morphological topographies ranging from a few centimetres up to several meters deep at sea level. When the present-day sea level differs from equivalent older features above or below the tidal range, coastal uplift or subsidence, respectively, can be inferred. Owing to the high seismic activity the Mediterranean, carbonatic coastlines can reveal many examples of raised tidal notches that have been measured and described in the past four decades (Pirazzoli et al., 1982, 1989, 1991; Pirazzoli, 1986; Firth et al., 1996; Laborel et al., 1999; Rust and Kershaw, 2000; Stiros et al., 2000; Kershaw and Guo, 2001; Shaw et al., 2008; Evelpidou et al., 2012a, 2014; Boulton and Stewart, 2015 Antonioli et al., 2015).

To facilitate the identification and comparison of former relative sea level stands represented through a variety of markers, such as tidal notches, Pirazzoli (1986) established a descriptive classification based on objectively determinable characteristics. Resultant from this classification tidal notches indicate the location of the midlittoral zone, which is vertically limited by the tidal range of maximum $0.3 \mathrm{~m}$ in the Mediterranean (Evelpidou et al., 2012b). Therefore, a vertical and sheltered exposure (Pirazzoli, 1986) of homogeneous bedrock (Pirazzoli and Evelpidou, 2013) is capable of forming a symmetrical V-shaped or U-shaped profile with its retreat point (hereafter: inflection point) at mean sea level.

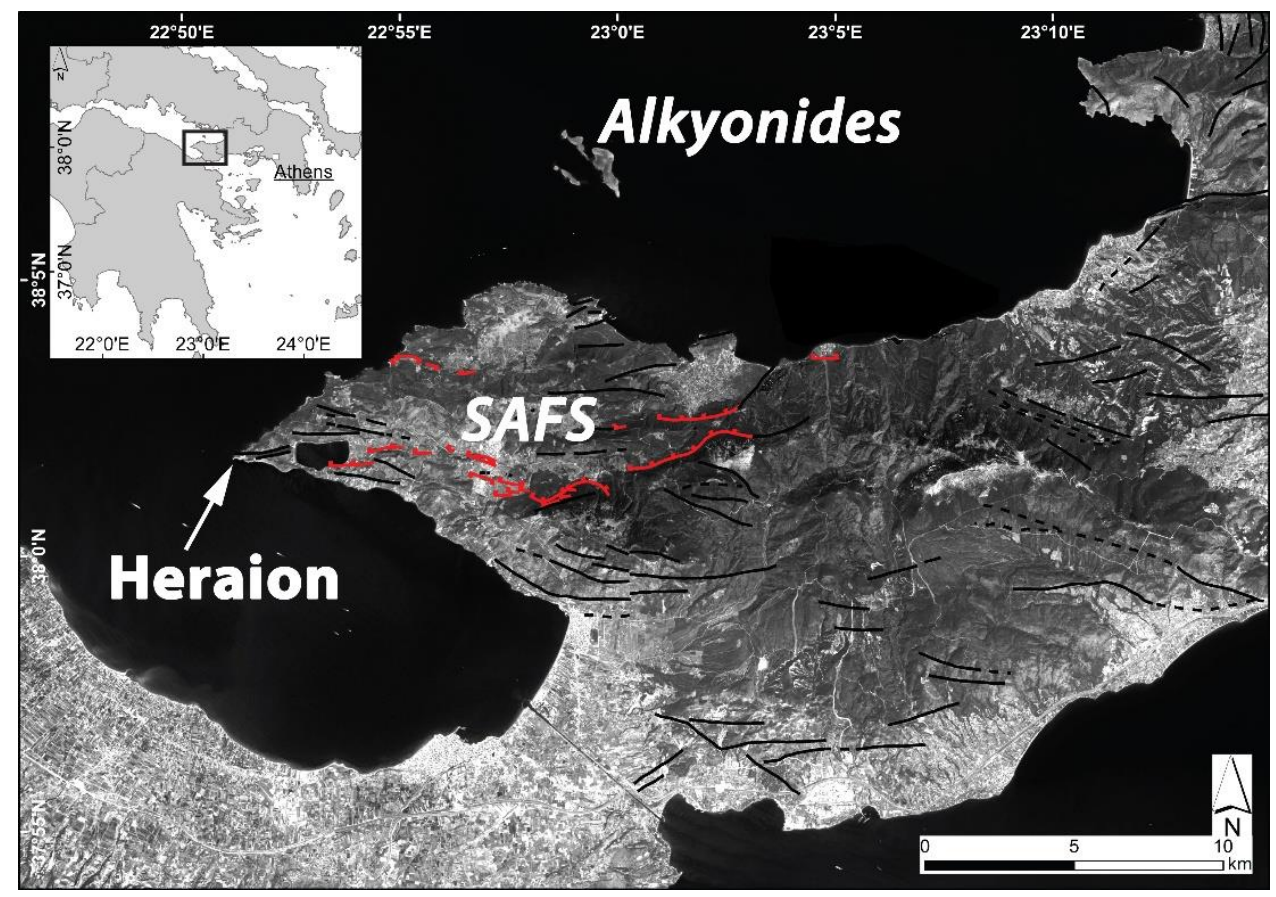

Figure 1 - Landsat 8 panchromatic image of Perachora Peninsula. Normal faults are derived from IGME geological maps (Black). Red faults were produced or reactivated during the 1981 earthquake sequence and are part of the South Alkyoides Fault System (SAFS). 
The database of Boulton and Stewart (2015) demonstrated that the formation of tidal notches is not linked to periods of stable or unstable climates in the past. Furthermore, the authors state that is likely that tectonic activity and earthquake clustering control the spatial and temporal distribution of tidal notches. This means that since the mid-Holocene rates of sea-level rise must match with rates of isostatic regional uplift to create a permanent, non-creeping erosional base. Only if a rapid offsetting event occurs, local midlittoral zone affects until then non-notched parts of rocky coastlines. However, the misconception that multiple and stacked notches are evidence for a metre-scale coseismic uplift produced by normal faulting event still persists.

In extensional tectonic settings commonly an uplift/subsidence-ratio of $1 / 2$ to $1 / 4$ for coseismic displacements is assumed (e.g. Stewart and Vita-Finzi, 1996; Armijo et al., 1996; McNeill et al., 2005; Papanikolaou et al., 2010). Pirazzoli et al. (1994) identified a series of four tidal notches of Holocene age at Heraion (Figure 1), each displaced by repeated uplifts of about $0.8 \pm 0.3 \mathrm{~m}$. Assuming a ratio of $1 / 4$ net slip per event, this would equate to $4 \mathrm{~m}$ total offset in an area where Jackson et al. (1982) reported just a minor coseismic uplift of $0.2 \mathrm{~m}$ during the Alkyonides earthquake sequence $(M=6.4-6.7)$ in spring 1981. This paradox raises questions on how to interpret tectonically controlled tidal notches in reference to palaeoseismic activities.

The investigation of palaeoshorelines at Perachora Peninsula has been the research objective of many studies. Influenced by vertical tectonic movements along active normal faults, such as the EW trending South Alkyonides Fault System (SAFS) (Collier et al., 1992; Armijo et al., 1996; Morewood and Roberts, 1999), the eastern Corinthian Gulf (Central Greece) exhibits evidence of multiple raised shorelines (Pirazzoli et al., 1994; Kershaw and Guo, 2001; Cooper et al., 2007; Roberts et al., 2009). Along the majority of Perachora Peninsula's shore Triassic and lower Jurassic Limestones of thick-bedded to massive biomicrites dominate (IGME, 1984); this is also the case at Heraion, at the western tip of the Peninsula.

In order to improve tidal notch identification and comparison on local to regional scales here the potential of high resolution t-LiDAR scans is introduced. Furthermore, selected notch profiles are interpreted utilizing geometrical shapes to extract Holocene coastal uplift history at Perachora Peninsula in the eastern Gulf of Corinth.

\section{Tidal notch formation}

The term tidal notch refers to a horizontal erosion feature at sea level (Kelletat, 2005) due to the coeval action (Antonioli et al., 2015) of chemical, physical, and biological factors (Pirazzoli, 1986). However, the predominant agent is commonly assumed to be bioerosion (Evelpidou et al., 2012). Thereby, sheltered and vertical exposures in microtidal environments are promising locations to preserve sea level markers of symmetrical shape. The occurrence of a spray zone in more exposed sites introduces a physicochemical component in terms of salt weathering. Subsequent deposition of salt crystals and hydration will modify the notch shape.

\subsection{Chemical component}

Dissolution of carbonates is not a common effect of seawater exposure, which is (over-) saturated with $\mathrm{CaCO}_{3}$ (Kelletat, 2005). However, Furlani and Cucchi (2013) have investigated downwearing rates of a limestone slab in the Adriatic Sea and presented comparable erosion rates to natural limestone surfaces. Furthermore, very localized, coastal sections next to springs may show evidence of solution by effluent groundwater (Evelpidou et al., 2012).

\subsection{Physical component}

Abrasion notches are characterized by a well-rounded profile and a smooth surface. Abrasion can only happen when there is a nearby source of sand and pebbles that can be transported in suspension (Pirazzoli, 1986). As a consequence, almost no organisms survive in these grinding environments (Kelletat, 2005). 
The vulnerability to different types of physical erosion on coastal cliffs is defined by the resistance of the rock to wave attack. The resistance is a function of lithology and structural discontinuities, such as cracks, fissures, joints, bedding planes, and faults. The rock is even more affected when turbulent water contains air that gets compressed when smashed against the rock and causes cavitation pitting (Antonioli et al., 2015).

\subsection{Biological component}

Bioerosion is restricted to carbonate rocks including calcarenites and dolomites (Kelletat, 2005). Surfaces appear with well-defined vegetational belts. The sublittoral zone of continuous immersion forms the habitat of grazing organisms like sea urchins that erode the underlying rock by abrading the surface with their hard teeth and radulas. Endolithic bivalves, such as the famous Lithophaga lithophaga but also limpets and chitons live in galleries at mean sea level. The supralittoral zone is only affected at high tide. Here, bioerosion is mainly caused by epilithic algae and cyanobacteria. These processes enable predominantly the development of a tidal notch with a maximum erosion rate at mean sea level (Evelpidou et al., 2012; Antonioli et al., 2015).

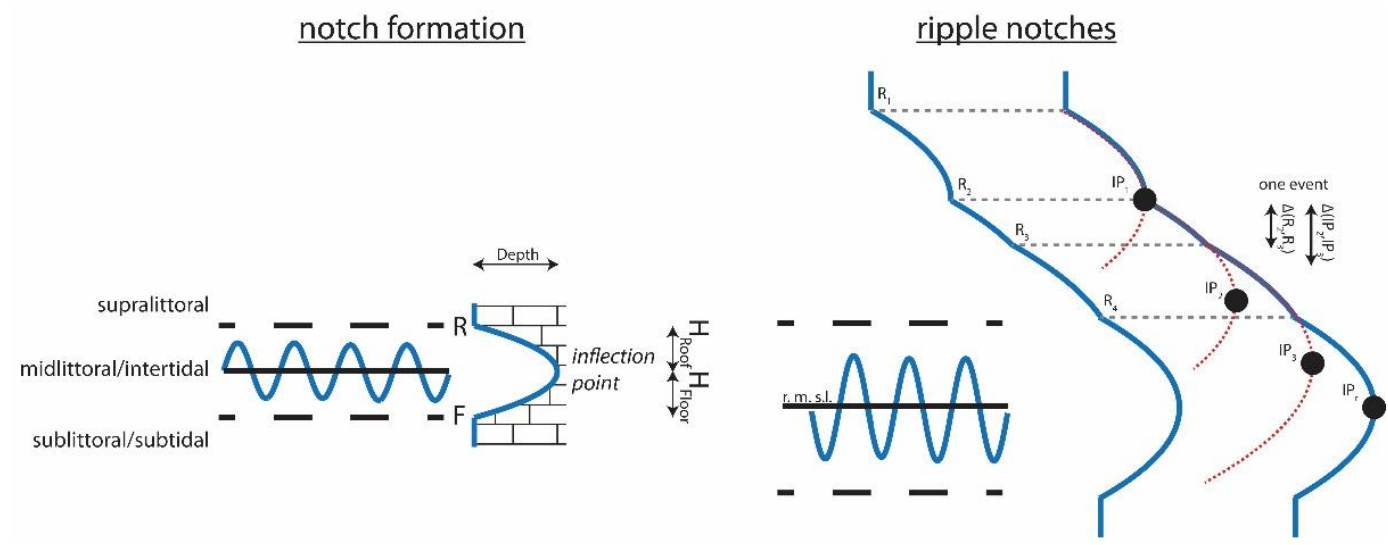

Figure 2 - Model tidal notch profile. Floor (F), Roof (R). Periodic erosion leads to a gradual incision into the vertical carbonatic coastal cliff. Maximum indentation is indicated by the reflection point (IP) near mean sea level. Ripple notches appear as witness of multiple emergence events and are not fully preserved due to overprint by younger notch developments. Notch elevation has to be measured at its inflection point.

\section{Geometrical shape of Holocene tidal notches}

The ratio between erosional components has not been discovered so far and most likely never will be because of the multiplicity of compounding factors. Pirazzoli (1986) depicts a model tidal notch profile that has been confirmed in many subsequent publications, such as by Laborel et al. (1999), Cooper et al. (2007), Evelpidou et al. (2012), Pirazzoli and Evelpidou (2013), Taboroši and Kázmér (2013) Boulton and Stewart (2015), or Trenhaile (2015) just to name a few. It consists of three main sections: I) A floor or base which extends to the limit of permanent immersion at tidal low stand; II) a retreat zone of maximum concavity exhibiting the inflection point near mean sea level, and III) a roof near high tide level (Figure 2). Incision into depth is described as gradually and successive towards the inflection point from both, floor and roof. The resulting most common profile follows a $\mathrm{U}$-shape or V-shape with the line of symmetry at mean sea level. Erosion appears to be most active where the environmental processes (discussed previously) interact frequently. The periodic parameter is given by the tide. Thus, mean sea level and deepest indentation have to meet at the centre of a symmetrical structure for the first order. Therefore, time controls the deep of a tidal notch if lithological, biological and climatic conditions are uniform. Generally observed for the 
Mediterranean are much lower values of 0.2 to $1.0 \mathrm{~mm} / \mathrm{a}$ (Pirazzoli and Evelpidou, 2013) but also down to $0.09 \mathrm{~mm} / \mathrm{a}$ (Furlani et al., 2011).

Shape modification of a stationary model tidal notch is given by exposure, and/or organic accretions (Pirazzoli, 1986; Antonioli et al., 2015). Increasing exposure yields an upwards shifted roof while the base remains at low tide level. Thus, the height of a notch is controlled by exposure to wave action (Evelpidou et al., 2012). Biological accretions are located at the base of a notch. If present the lower part of the notch is no longer a mirrored copy of the upper part but reduced in size.

Pirazzoli (1986) also introduced different scenarios for resulting notch profiles according to relative sea level changes. When considering tidal notches of Holocene age, relative land movements are suggested to be a better frame of reference. Since sea level rise and regional uplift are of the same rate and produce a relative direction vector of almost zero, except for when coastal tectonic activity overprints this trajectory (Boutlon and Stewart, 2015). Thus, sudden emergence exceeding the tidal range will enable a new entire tidal notch to be formed at the newly created erosional base within the tidal zone. If abrupt emergence does not exceed the tidal range an overlapping of the former and new erosional zones occurs. This causes an overprinting of the earlier notch and on raised notches the floor gets attacked and degraded. Pirazzoli (1986) labels features of this origin 'ripple notches'. However, dependent on time and vertical displacement, the resulting shape is tantamount to a widened single notch; for instance, because of tidal range variation. Only at close range will minor variations be detectable on the surface curvature of the roof.

\section{Methodology}

In general, the identification of a palaeoshoreline is, among other things (bioerosional leftovers, consolidated beach deposits), based on the recognition of distinct erosional marks of the former midlittoral zone (Pirazzoli et al., 1994). Typically, the notch position is mapped on a 1:5000-scale map (Cooper et al., 2007) and measurements to create morphometric profile will be made, these include the average vertical extent of a notch and the maximum indentation (e.g. Antonioli et al., 2015). Traditionally, these profiles are collected by tape measure (e.g. Kershaw and Guo, 2001). However, vertical sheltered coasts preferred for the precise measurement of tidal notches (Pirazzoli, 1986), yet often these cliffs are inaccessible. Therefore, Kázmér and Taboroši (2012) show how to perform rapid profiling of marine notches from a distance using a handheld laser distance meter.

Terrestrial laser scanning (TLS) has been applied already for monitoring coastal geomorphological aspects (e.g. Hoffmeister et al., 2012; Rosser et al., 2013). In addition to horizontal (x) and vertical (z) distance measurements (Kázmér and Taboroši, 2012) TLS provides a third spatial dimension (y) and, dependent on the system, information about the backscattered signal (i). The technology is nonselective and non-invasive to surfaces and the resulting point cloud data is of high accuracy and precision (Smith, 2015) representing x,y,z (i) attributes.

For this study, two sites at Heraion were scanned using a Faro Focus 3D X330 scanner at low tide. Benefits of this system is its flexibility and weight, since the ideal scanning position is almost perpendicular to the exposure (e.g. Höfle and Pfeifer, 2007) and oftentimes hard to access on steep rocky cliffs. The raw point cloud data was cleaned from noise and outliers. Internal sensors of the scanner recorded the inclination. If multiple scans were necessary, the iterative closest point (ICP) algorithm was applied to enhance the registration (Besl and McKay, 1992). Sequential vertical profiles were then extracted from the point cloud data. A visual inspection of these profiles using predefined symmetrical shapes was then used to identify erosional marks at different elevations (Figure 3).

\section{Results}

Erosional marks at the Heraion Lighthouse site have been investigated by Pirazzoli et al. (1994) (Figure 3a). Results from TLS analysis show distinct and continuous multilevel horizontal texturing 
of the exposure without misleading illumination and shadowing. The two-dimensional profile analysis detects not only the four already published tidal notches (here: $+0.9 \mathrm{~m},+1.5 \mathrm{~m},+2.5 \mathrm{~m}$, and $+2.9 \mathrm{~m})$ but also points on additional four evidence of sea level erosion $(+0.4 \mathrm{~m},+1.9 \mathrm{~m},+2.1 \mathrm{~m}$, and $+2.3 \mathrm{~m} \pm 0.2 \mathrm{~m})$ (Figure $3 \mathrm{c})$. Significant knickpoints and their horizontal continuity over the exposures' extent depict first indications of historical relative sea levels (Figure 2). Parabolic shapes of similar shortening or stretching were then matched to the profile to recalculate associated inflection points. For all above mentioned particular marks these vary along a horizontal level for about $0.1 \mathrm{~m}$.

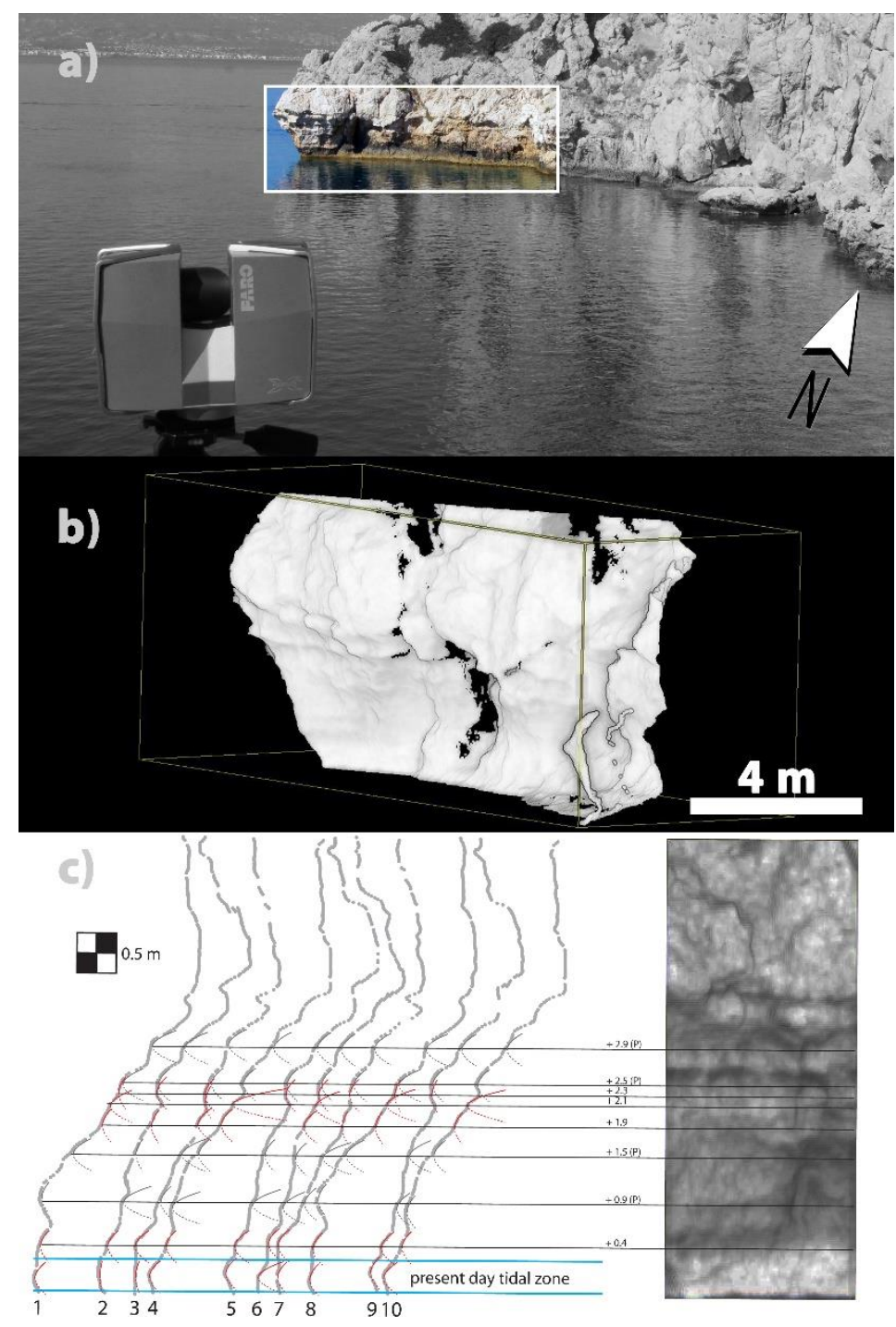

Figure 3 - a) scanning position and scan window at the Heraion Lighthouse site $\left(38^{\circ}\right.$ $\left.1^{\prime} 40.75^{\prime \prime} \mathrm{N}, 22^{\circ} 51^{\prime} 4.05 " \mathrm{E}\right)$. b) High-resolution dense point cloud data already indicates horizontal texture. c) Results of overall 2D point profile analyses. Shown are 10 random profiles extracted from scan. Gray parabola point on erosional marks already mentioned by Pirazolli et al. (1994) (P). Red parabolae denote profile sections of similar shapes.

A second cliff was scanned at the beach site of Heraion. While the above mentioned south-facing cliff is sheltered, this second exposure is almost open to the Gulf of Corinth (see also Kershaw and Guo, 2001) (Figure 4). Hence, erosional forces have greater impact on the cliff and result in 
modification from the idealised tidal notch model. Obvious changes are carved and broken sections of cliff along shore (Figure $4 \mathrm{a}+\mathrm{b}$ ). As a consequence, the excellent preservation of continuous horizontal erosional marks at the lighthouse site is no longer present. However, both, threedimensional point cloud data as well as sequential 2D-profiles highlight evidence for raised shorelines (Figure $4 b+c$ ).

Five extracted levels of consistent inflection points match up and complement the local notch sequence. Marks at the beach site have been raised to $+0.8 \mathrm{~m},+1.6 \mathrm{~m}$, and $+3.0 \mathrm{~m}$ correlating to those features at $+0.9 \mathrm{~m},+1.5 \mathrm{~m}$, and $+2.9 \mathrm{~m}$ seen $\sim 300 \mathrm{~m}$ to the west. Another match between both sites is located at $+1.9 \mathrm{~m}$. Furthermore, at least three more indentations $(+0.4 \mathrm{~m}$, $+0.8 \mathrm{~m}$, and $+2.1 \mathrm{~m}$ ) are reasonable complements to the local palaeoshoreline sequence.
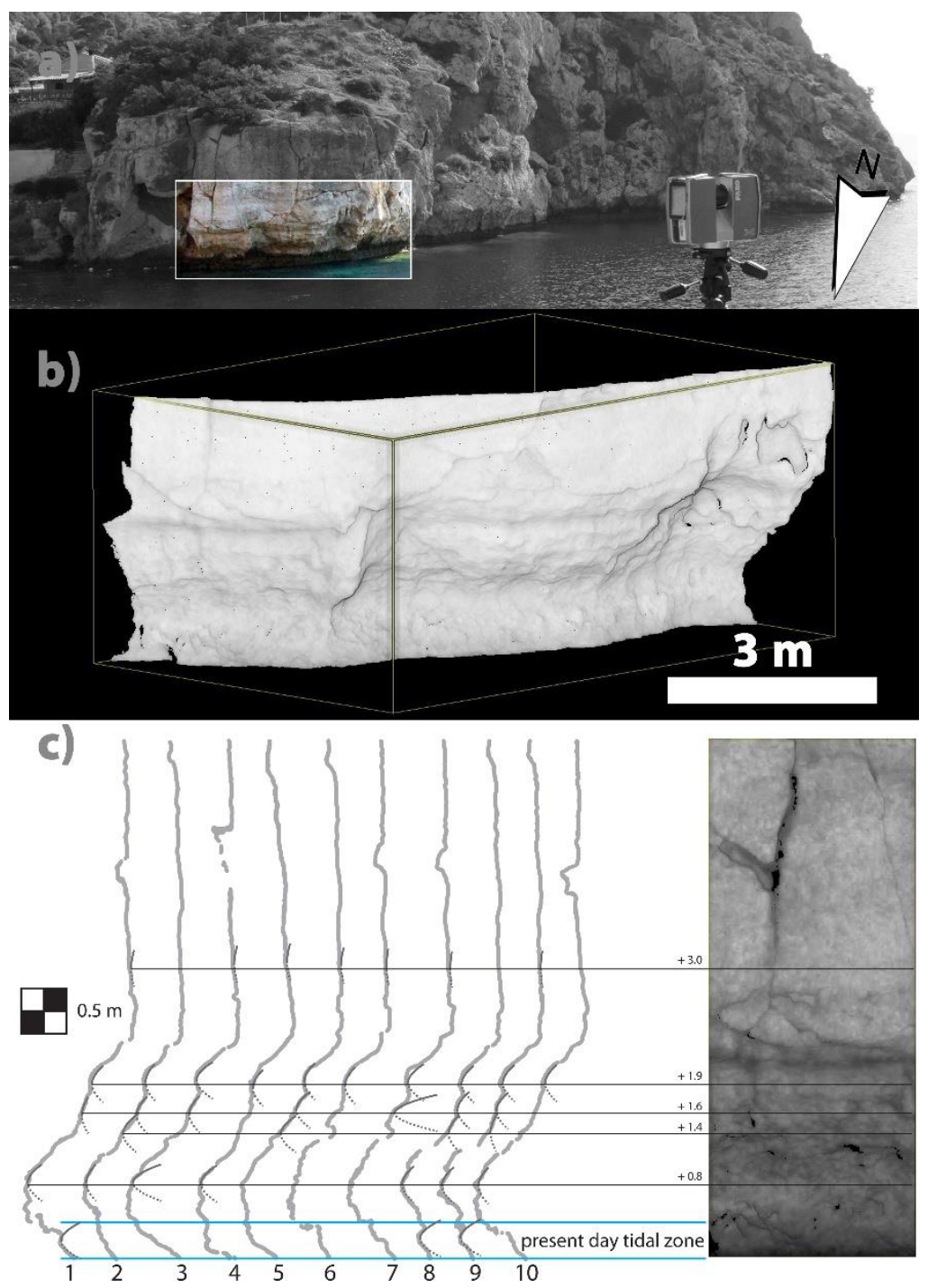

Figure 4 - a) Tidal Notch exposure at the Heraion Beach site. Scanning position: $38^{\circ}$ 1'39.51'N, 22 51 '8.34"E. b) High-resolution point cloud emphasising erosional texture. c)

Randomly selected 2D-profiles that represent extracted the former erosional bases. 


\section{Discussion and concluding marks}

Tidal notches form at sea level with a vertical extension almost equal to the tidal range (e.g. Pirazzoli, 1986). When emerged, these erosional marks indicate tectonic uplift within the past 6,000 years (Boulton and Steward, 2015). A model tidal notch is gradually influenced by time and exposure (e.g. Pirazzoli, 1986; Evelpidou et al., 2012; Pirazzoli and Evelpidou, 2013; Taboroši and Kázmér, 2013; Trenhaile, 2015) that leads to a symmetrical shape with mean sea level as centre line. Following this assumption predefined symmetrical shapes, such as parabola, could be applied to detect erosional indentations and project to associated inflection points. Since tectonic uplift is a minor amount of coseismic displacements, vertical differences on a metre-scale between two notches are not reasonable for single and successive normal faulting earthquake events. More common are uplifting values in the order of a few decimetres (Papanikolaou et al., 2010). Hence, a mesoscale downward widening of pre-existing tidal notches is likely. The former notch floor as well as biological markers, such as Lithophaga agents, could be overprinted by the newer tidal notch generation. Thus, minor but horizontally consistent changes in the surfaces' curvature might be evidence for sea level indicators that were eroded along their lower extent over time, or did not have enough time to develop because of short recurrence intervals between uplift events. Thereby, the local tidal amplitude $( \pm 0.2 \mathrm{~m})$ forms the resolution limit. Dependent on stretching or shortening of the symmetrical shape, the inflection point varies vertically. Thus, it is absolutely necessary to measure the elevation of inflection points rather than the vertical difference between two roofs (Figure 2).

Based on the shape and geometrical appearance of the existing raised shoreline sequence, the four shorelines recognised by Pirazzoli et al. (1994) could be complemented by four additional levels (+ $0.4 \mathrm{~m},+0.9 \mathrm{~m},+1.5 \mathrm{~m},+1.9 \mathrm{~m},+2.1 \mathrm{~m},+2.3 \mathrm{~m},+2.5 \mathrm{~m}$, and $+2.9 \mathrm{~m}$, each $\pm 0.2 \mathrm{~m})$ on the western tip of Perachora Peninsula. Each level was extracted by a mean of recalculated inflection points of parabolic shapes horizontally traceable along the exposure. Therefore, high-resolution TLS surveys were applied to coastal cliffs at enabling close-up views all over exposures' extensions. Slicing the digital cliff into multiple sequential profiles of equal dimensions enhances the representative value of notch profiling. Along the coastline on local scale notch profile heterogeneity can be observed. Cliff collapse, fractional sections, and bedrock heterogeneity lead to significant deviations of notch profiling results (Kershaw and Guo, 2001) (e.g. Figure 4 Profiles 4 and 10). Hence, site selection and a representative number of profiles are essential for rigorous analysis. In conclusion, utilising TLS measurements in notch studies presents the opportunity to collect high resolution spatial data from exposures in a rectified manner, which is not possible using conventional tape measuring and photomosaic methods.

\section{Acknowledgments}

The Hellenic Navy Hydrographic Service provided tidal range data from Posidonia Station at the Corinth Canal for the period of scanning. Thanks to C. Hilgers and his team of the Institute of Reservoir and Petrology (RWTH Aachen University) for the loan of the TLS System. Further, T. M. Fernández-Steeger (RWTH Aachen University) is acknowledged for financial support.

\section{References}

Antonioli, F., Lo Presti, V., Rovere, A., Ferranti, L., Anzidei, M., Furlani, S., Mastronuzzi, G., Orru, P.E., Scicchitano, G., Sannino, G., Spampinato, C.R., Paglirulo, R., Deiana, G., de Sabata, E., Sansò, P., Vacchi, M. and Vecchio, A., 2015. Tidal notches in Mediterranean Sea: a comprehensive analysis, Quaternary Science Reviews, 119, 66-84, doi: 10.1016/j.quascirev.2015.03.016.

Armijo, R., Meyer, B., King, G.C.P., Rigo, A. and Papanastassiou, D., 1996. Quaternary evolution of the Corinth Rift and its implications for the Late Cenozoic evolution of the Aegean, Geophysical Journal International, 126(1), 11-53, doi: 10.1111/j.1365246X.1996.tb05264.x. 
Besl, P.J. and McKay, H.D., 1992. A method for registration of 3-D shapes, IEEE Trans. Pattern Anal. Machine Intell., 14(2), 239-256, doi: 10.1109/34.121791.

Boulton, S.J. and Stewart, I.S., 2015. Holocene coastal notches in the Mediterranean region: Indicators of palaeoseismic clustering? Geomorphology, 237, 29-37, doi: 10.1016/j.geomorph.2013.11.012.

Collier, R.E.L., Leeder, M.R., Rowe, P.J. and Atkinson, T.C., 1992. Rates of tectonic uplift in the Corinth and Megara Basins, central Greece, Tectonics, 11(6), 1159-1167, doi: 10.1029/92TC01565.

Cooper, F.J., Roberts, G.P. and Underwood, C.J., 2007. A comparison of 103 -10 5 year uplift rates on the South Alkyonides Fault, central Greece: Holocene climate stability and the formation of coastal notches, Geophys. Res. Lett., 34(14), doi: 10.1029/2007GL030673.

Evelpidou, N., Kampolis, I., Pirazzoli, P.A. and Vassilopoulos, A., 2012. Global sea-level rise and the disappearance of tidal notches, Global and Planetary Change, 92-93, 248-256, doi: 10.1016/j.gloplacha.2012.05.013.

Evelpidou, N., Melini, D., Pirazzoli, P.A. and Vassilopoulos, A., 2014. Evidence of repeated late Holocene rapid subsidence in the SE Cyclades (Greece) deduced from submerged notches, Int. J. Earth Sci. (Geol Rundsch), 103(1), 381-395, doi: 10.1007/s00531-013-0942-0.

Evelpidou, N., Vassilopoulos, A. and Pirazzoli, P.A., 2012. Submerged notches on the coast of Skyros Island (Greece) as evidence for Holocene subsidence, Geomorphology, 141-142, 8187, doi: 10.1016/j.geomorph.2011.12.025.

Firth, C., Stewart, I., McGuire, W.J., Kershaw, S. and Vita-Finzi, C., 1996. Coastal elevation changes in eastern Sicily: implications for volcano instability at Mount Etna, Geological Society, London, Special Publications, 110(1), 153-167, doi: 10.1144/GSL.SP.1996.110.01.12.

Furlani, S. and Cucchi, F., 2013. Downwearing rates of vertical limestone surfaces in the intertidal zone (Gulf of Trieste, Italy), Marine Geology, 343, 92-98, doi: 10.1016/j.margeo.2013.06.005.

Hoffmeister, D., Tilly, N., Curdt, C., Aasen, H., Ntageretzis, K., Hadler, H., Willershäuser, T., Vött, A. and Bareth, G., 2012. Terrestrial laser scanning for coastal geomorphologic research in western Greece, Int. Arch. Photogramm. Remote Sens. Spatial Inf. Sci., XXXIX/B5, 511516, doi: 10.5194/isprsarchives-XXXIX-B5-511-2012.

Höfle, B. and Pfeifer, N., 2007. Correction of laser scanning intensity data: Data and model-driven approaches, ISPRS Journal of Photogrammetry and Remote Sensing, 62(6), 415-433, doi: 10.1016/j.isprsjprs.2007.05.008.

Kázmér, M. and Taboroši, D., 2012. Rapid Profiling of Marine Notches Using a Handheld Laser Distance Meter, Journal of Coastal Research, 283, 964-969, doi: 10.2112/JCOASTRES-D11-00163.1.

Kelletat, D.H., 2005. Notches. Encyclopedia of Coastal Science, In: Schwartz, M.L., ed., Springer, Dordrecht.

Kershaw, S. and Guo, L., 2001. Marine notches in coastal cliffs: indicators of relative sea-level change, Perachora Peninsula, central Greece, Marine Geology, 179(3-4), 213-228, doi: 10.1016/S0025-3227(01)00218-3.

Laborel, J., Morhange, C., Collina-Girard, J. and Laborel-Deguen, F., 1999. Littoral bioerosion, a tool for the study of sea level variations during the Holocene, Bulletin of the Geological Society of Denmark, 45, 164-168.

McNeill, L.C., Cotterill, C.J., Henstock, T.J., Bull, J.M., Stefatos, A., Collier, R.E.Ll., Papatheoderou, G., Ferentinos, G. and Hicks, S.E., 2005. Active faulting within the offshore western Gulf of Corinth, Greece: Implications for models of continental rift deformation, Geol., 33(4), 241, doi: 10.1130/G21127.1.

Morewood, N.C. and Roberts, G.P., 1999. Lateral propagation of the surface trace of the South Alkyonides normal fault segment, central Greece: its impact on models of fault growth and displacement-length relationships, Journal of Structural Geology, 21(6), 635-652, doi: 10.1016/S0191-8141(99)00049-8. 
Papanikolaou, I.D., Foumelis, M., Parcharidis, I., Lekkas, E.L. and Fountoulis, I.G., 2010. Deformation pattern of the 6 and 7 April 2009, MW=6.3 and MW=5.6 earthquakes in L'Aquila (Central Italy) revealed by ground and space based observations, Nat. Hazards Earth Syst. Sci., 10(1), 73-87, doi: 10.5194/nhess-10-73-2010.

Papavassiliou, C., 1984. Geological Map of Greece, 1:50.000. Perachora Sheet, Institute of Geology and Mineral Exploration (IGME).

Pirazzoli, P.A., Laborel, J., Saliège, J.F., Erol, O., Kayan, İ. and Person, A., 1991. Holocene raised shorelines on the Hatay coasts (Turkey): Palaeoecological and tectonic implications, Marine Geology, 96(3-4), 295-311, doi: 10.1016/0025-3227(91)90153-U.

Pirazzoli, P.A., Montaggioni, L.F., Saliège, J.F., Segonzac, G., Thommeret, Y., Vergnaud and Grazzini, C., 1989. Crustal block movements from Holocene shorelines: Rhodes Island (Greece), Tectonophysics, 170(1-2), 89-114, doi: 10.1016/0040-1951(89)90105-4.

Pirazzoli, P.A., Stiros, S.C., Arnold, M., Laborel, J., Laborel-Deguen, F. and Papageorgiou, S., 1994. Episodic uplift deduced from Holocene shorelines in the Perachora Peninsula, Corinth area, Greece, Tectonophysics, 229(3-4), 201-209, doi: 10.1016/0040-1951(94)90029-9.

Pirazzoli, P.A., Thommeret, J., Thommeret, Y., Laborel, J. and Montag-Gioni, L.F., 1982. Crustal block movements from holocene shorelines: Crete and antikythira (Greece), Tectonophysics, 86(1-3), 27-43, doi: 10.1016/0040-1951(82)90060-9.

Pirazzoli, P.A. and Evelpidou, N., 2013. Tidal notches: A sea-level indicator of uncertain archival trustworthiness, Palaeogeography, Palaeoclimatology, Palaeoecology, 369, 377-384, doi: 10.1016/j.palaeo.2012.11.004.

Roberts, G.P., Houghton, S.L., Underwood, C., Papanikolaou, I., Cowie, P.A., van Calsteren, P. Wigley, T., Cooper, F.J. and McArthur, J.M., 2009. Localization of Quaternary slip rates in an active rift in 105 years: An example from central Greece constrained by $234 \mathrm{U}-230 \mathrm{Th}$ coral dates from uplifted paleoshorelines, J. Geophys. Res., 114(B10), doi: 10.1029/2008JB005818.

Rosser, N.J., Brain, M.J., Petley, D.N., Lim, M. and Norman, E.C., 2013. Coastline retreat via progressive failure of rocky coastal cliffs, Geology, 41(8), 939-942, doi: 10.1130/G34371.1.

Rust, D. and Kershaw, S., 2000. Holocene tectonic uplift patterns in northeastern Sicily: evidence from marine notches in coastal outcrops, Marine Geology, 167(1-2), 105-126, doi: 10.1016/S0025-3227(00)00019-0.

Shaw, B., Ambraseys, N.N., England, P.C., Floyd, M.A., Gorman, G.J., Higham, T.F.G., Jackson, J.A., Nocquet, J.-M., Pain, C.C. and Piggott, M.D., 2008. Eastern Mediterranean tectonics and tsunami hazard inferred from the AD 365 earthquake, Nature Geosci., 1(4), 268-276, doi: 10.1038/ngeo151.

Smith, M.W., 2015. Direct acquisition of elevation data: Terrestrial Laser Scanning. Geomorphological Techniques (Online Edition). In: Clarke, K.E. and Nield, J.M., eds., British Society for Geomorphology, London, UK.

Stewart, I. and Vita-Finzi, C., 1996. Coastal uplift on active normal faults: The Eliki Fault, Greece, Geophys. Res. Lett., 23(14), 1853-1856, doi: 10.1029/96GL01595.

Stiros, S.C., Laborel, J., Laborel-Deguen, F., Papageorgiou, S., Evin, J. and Pirazzoli, P.A., 2000. Seismic coastal uplift in a region of subsidence: Holocene raised shorelines of Samos Island, Aegean Sea, Greece, Marine Geology, 170(1-2), 41-58, doi: 10.1016/S0025-3227(00)00064-5.

Taboroši, D. and Kázmér, M., 2013. Erosional and Depositional Textures and Structures in Coastal Karst Landscapes. In: Lace, M.J. and Mylroie, J.E., eds., Coastal Karst Landforms, vol. 5. Dordrecht: Springer Netherlands (Coastal Research Library), 15-57.

Trenhaile, A.S., 2015. Coastal notches: Their morphology, formation, and function, Earth-Science Reviews, 150, 285-304, doi: 10.1016/j.earscirev.2015.08.003. 